University of Nebraska - Lincoln

DigitalCommons@University of Nebraska - Lincoln

Leaching of Phosphorus Fractions Following Manure or Compost Application

\author{
Bahman Eghball \\ United States Department of Agriculture, beghball1@unl.edu
}

Follow this and additional works at: https://digitalcommons.unl.edu/usdaarsfacpub

Part of the Agricultural Science Commons

Eghball, Bahman, "Leaching of Phosphorus Fractions Following Manure or Compost Application" (2003). Publications from USDA-ARS / UNL Faculty. 530.

https://digitalcommons.unl.edu/usdaarsfacpub/530

This Article is brought to you for free and open access by the U.S. Department of Agriculture: Agricultural Research Service, Lincoln, Nebraska at DigitalCommons@University of Nebraska - Lincoln. It has been accepted for inclusion in Publications from USDA-ARS / UNL Faculty by an authorized administrator of DigitalCommons@University of Nebraska - Lincoln. 


\title{
Leaching of Phosphorus Fractions Following Manure or Compost Application ${ }^{\#}$
}

\author{
Bahman Eghball* \\ USDA-ARS, University of Nebraska-Lincoln, Lincoln, Nebraska, USA
}

\begin{abstract}
Phosphorus $(\mathrm{P})$ leaching in manure-amended soil can be influenced by the $\mathrm{P}$ fractions added when manure or composted manure is applied. This study was conducted to determine leaching of different $\mathrm{P}$ fractions following beef cattle feedlot manure or compost application. Manure and composted manure were applied to meet the nitrogen $(\mathrm{N})$ or $\mathrm{P}$ needs of corn (Zea mays L.) for either a one or two-yr period. Fertilized plots and unfertilized control plots were also used. The P-based treatments also received additional $\mathrm{N}$ fertilizer. Soil $\mathrm{P}$ fractions were determined for various soil depth increments. After 4 years of manure and compost applications, leaching of plant-available $\mathrm{P}$ was observed to a soil depth of $30 \mathrm{~cm}$. The differences among treatments for total and inorganic $\mathrm{P}$ were significant only at the 0 to $15 \mathrm{~cm}$ soil depth increment. Greater
\end{abstract}

\footnotetext{
\#Joint contribution of USDA-ARS and University of Nebraska Agricultural Research Division, Lincoln, NE, as paper No. 13435.

*Correspondence: Bahman Eghball, USDA-ARS, 121 Keim Hall, University of Nebraska-Lincoln, Lincoln, NE, 68583, USA; E-mail: beghball1@unl.edu.
} 
concentrations of total, available, and inorganic $\mathrm{P}$ fractions were observed for the N-based manure and compost treatments as these management strategies received more $\mathrm{P}$ than P-based. More than $70 \%$ of beef cattle manure or composted feedlot manure $\mathrm{P}$ was inorganic. Watersoluble $\mathrm{P}$ was a small fraction of total $\mathrm{P}$ in beef cattle feedlot manure or composted manure $(<13 \%)$. Leaching of plant-available $\mathrm{P}$ following manure and compost applications can pollute the ground water if $\mathrm{P}$ comes in contact with ground water, especially in areas with shallow and/or fluctuating ground water and in areas with till drainage.

Key Words: Cattle manure; Eutrophication; N-based; P-based; $\mathrm{P}$ movement; Water quality.

\section{INTRODUCTION}

Phosphorus from long-term manure or fertilizer application or from heavy loading of manure, can leach into ground water in areas with shallow water tables or coarse-textured soils. Phosphorus leaching to a soil depth of $1.8 \mathrm{~m}$ was observed with long-term ( $>50 \mathrm{yr}$ ) beef cattle feedlot manure application. ${ }^{[1]}$ They found leaching of $\mathrm{P}$ from chemical fertilizer to be shallower than similar loading of manure $\mathrm{P}\left(\sim 84 \mathrm{~kg} \mathrm{P}^{-1} \mathrm{year}^{-1}\right)$. It was hypothesized that manure contained $\mathrm{P}$ fractions that were not susceptible to adsorption by a calcium carbonate layer in this soil and would thus be more likely to leach deeper into the soil than fertilizer P. Land application of cattle feedlot manure resulted in increased soil levels of total, inorganic, organic, and available $\mathrm{P}$, and decreased $\mathrm{P}$ sorption capacity to a depth of $0.3 \mathrm{~m}^{[2]}$ Mozaffari and Sims ${ }^{[3]}$ found $\mathrm{P}$ movement to a depth of $0.4 \mathrm{~m}$ in soils receiving poultry manure. Sims et al. ${ }^{[4]}$ reported an extensive review of $\mathrm{P}$ loss in agricultural drainage when manure or fertilizer was applied to different soils and found significant leaching of $\mathrm{P}$ following manure application. When $\mathrm{P}$ leaches through soil, it can eventually reach the ground water. In many cases, ground water emerges as surface water and thus can contribute to eutrophication if it contains sufficient $\mathrm{P}$.

Manures from different animal species differ in their composition, which influences their environmental impacts. Chemical fractionation techniques have been used to identify the various forms of $\mathrm{P}$ in soils receiving wastewater, ${ }^{[5]}$ municipal sludge,${ }^{[6,7]}$ cattle feedlot waste,${ }^{[2]}$ and poultry litter. ${ }^{[8]}$ These $\mathrm{P}$ fractions can have different effects on the environment.

Applying manure or compost to meet corn $\mathrm{N}$ requirements can greatly increase soil $\mathrm{P}$ level as compared with P-based applications. ${ }^{[9]}$ This is because the N:P ratios of manure and composted manure are significantly 
smaller than N:P uptake ratios of most crops. This unused $\mathrm{P}$ can be transported in runoff or leach further into the soil profile. Soil $\mathrm{P}$ fractions following manure and compost applications can have a significant effect on the amount of $\mathrm{P}$ leached or lost in runoff. The objective of this study was to fractionate $\mathrm{P}$ in manure, composted manure, and soil receiving annual or biennial applications of $\mathrm{N}$ or $\mathrm{P}$-based manure and compost to assess $\mathrm{P}$ leaching.

\section{MATERIALS AND METHODS}

A field experiment was initiated in 1992 on a Sharpsburg silty clay loam soil (fine, smectitic, mesic Typic Argiudoll) under rainfed (dryland) conditions at the University of Nebraska Agricultural Research Center near Mead, NE. The Sharpsburg series consists of deep, moderately well drained soils formed in loess on uplands and high benches. Permeability is moderately slow in the upper part and moderate in the lower part. Selected soil characteristics are given in Table 1. Additional information regarding soil properties during four years of manure and compost applications is given in Eghball. ${ }^{[10]}$ The experimental design was a randomized complete block with four replications. The ten treatments included annual or biennial manure or compost applications based on $\mathrm{N}$ or $\mathrm{P}$ removal of corn $(151 \mathrm{~kg} \mathrm{~N}$ $\mathrm{ha}^{-1}$ and $25.8 \mathrm{~kg} \mathrm{P} \mathrm{ha}^{-1}$ for an expected yield level of $\left.9.4 \mathrm{Mg} \mathrm{ha}^{-1}\right)^{[11]}$ and fertilized and unfertilized checks. Fertilizer application was made in the spring each year. If necessary, the P-based treatments (annual or biennial application) also received $\mathrm{N}$ fertilizer as ammonium nitrate (34-0-0, N-P-K) in the spring so that a total of $151 \mathrm{~kg} \mathrm{~N} \mathrm{ha}^{-1}$ was available to the crop.

Beef cattle manure was collected from the feedlot pens in late spring each year and composted for about 4 months using active composting (with turning). Beef cattle feedlot manure (collected in the autumn) and

Table 1. Selected characteristics of the soil in 1996 following four years of manure, compost, and fertilizer applications (averaged across treatments) at Mead, NE.

\begin{tabular}{|c|c|c|c|c|c|c|c|c|}
\hline \multirow{2}{*}{$\begin{array}{l}\text { Soil depth } \\
\text { (cm) }\end{array}$} & Total C & Total N & \multirow[b]{2}{*}{$\mathrm{pH}$} & \multirow{2}{*}{$\begin{array}{c}\mathrm{EC} \\
\left(\mathrm{d} \mathrm{S} \mathrm{m}^{-1}\right)\end{array}$} & \multirow{2}{*}{$\begin{array}{l}\text { Bulk density } \\
\left(\mathrm{Mg} \mathrm{m}^{-3}\right)\end{array}$} & \multirow[t]{2}{*}{ Sand } & \multirow{2}{*}{\multicolumn{2}{|c|}{$\frac{\text { Silt }}{(\%)}$}} \\
\hline & \multicolumn{2}{|c|}{$\left(\mathrm{g} \mathrm{kg}^{-1}\right)$} & & & & & & \\
\hline $0-15$ & 22.3 & 2.0 & 6.3 & 0.32 & 1.2 & 8.3 & 66.9 & 24.8 \\
\hline $15-30$ & 18.7 & 1.6 & 6.3 & 0.23 & 1.39 & 8.0 & 68.8 & 23.1 \\
\hline $30-60^{\dagger}$ & - & - & 6.7 & 0.24 & 1.38 & 9.0 & 67.9 & 23.1 \\
\hline $60-90^{\dagger}$ & - & - & 6.5 & 0.37 & 1.47 & 7.4 & 57.7 & 34.9 \\
\hline
\end{tabular}

${ }^{\dagger}$ Total $\mathrm{C}$ and $\mathrm{N}$ were not determined. 


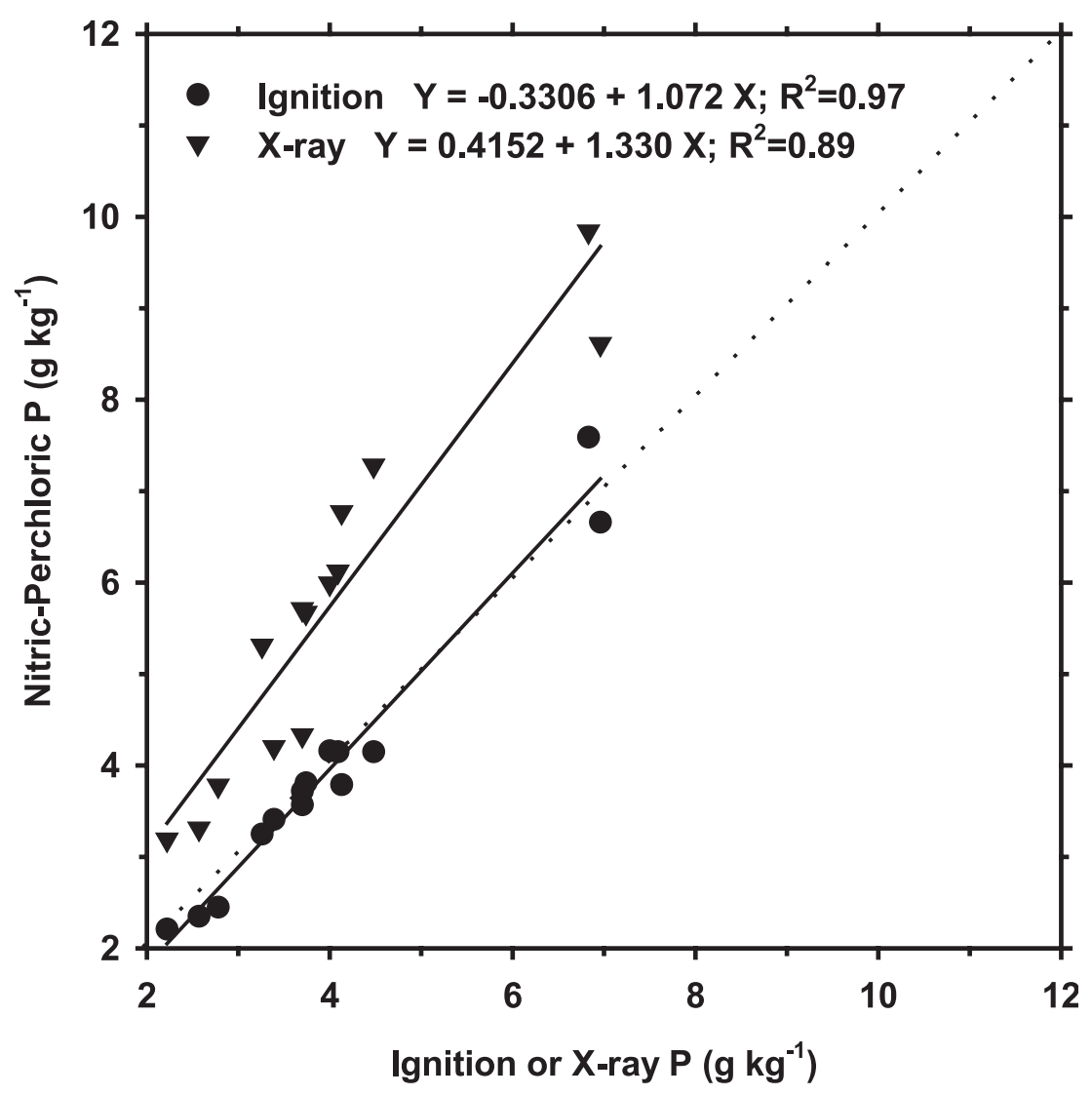

Figure 1. Total $\mathrm{P}$ in dry beef cattle feedlot manure or composted manure as determined by the Nitric-Perchloric, ${ }^{[13]}$ Ignition, ${ }^{[12]}$ and X-ray ${ }^{[14]}$ methods. The dotted line is the $1: 1$ ratio.

composted feedlot manure were applied in the autumn of 1992 based on the assumption that $40,20,10$, and $5 \%$ of the $\mathrm{N}$ and $\mathrm{P}$ in manure or compost would become plant-available in the first, second, third, and fourth yr after application, respectively, based on a modification of the decay series given in Gilbertson et al. ${ }^{[11]}$ The first yr $\mathrm{N}$ availability assumption from compost was found to be too high, therefore availability assumptions were changed to $20,20,10,5 \%$ in the first, second, third and fourth yr for compost applications made in 1993, 1994, and 1995 . The $\mathrm{N}$ availability assumptions used in $1992(40,20,10,5 \%)$ were used for manure in the other three years. Phosphorus availability assumptions from manure and compost were 


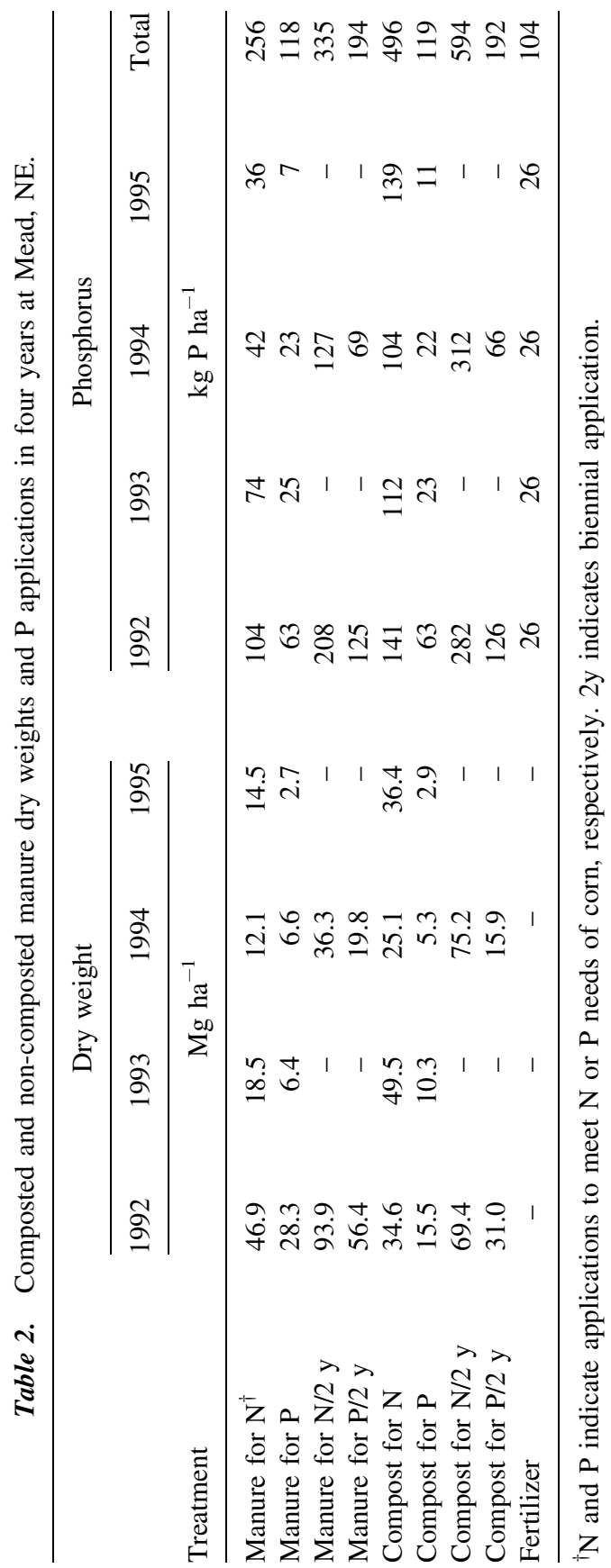


changed to $60,20,10,10 \%$ in the first, second, third, and fourth yr for applications made in 1993, 1994, and 1995. Biennial manure or compost applications were made to provide $151 \mathrm{~kg} \mathrm{~N}^{-1}$ for $\mathrm{N}$-based and $25.8 \mathrm{~kg}$ $\mathrm{P} \mathrm{ha}^{-1}$ for P-based rates in the second $\mathrm{yr}$ after application based on the assumptions given above. Residual $\mathrm{N}$ and $\mathrm{P}$ values from previous years were considered when manure or compost was applied.

Manure or compost application was made in late autumn after corn harvest. Manure and compost were applied by hand to plots $12.2 \mathrm{~m}$ long and $4.6 \mathrm{~m}$ wide (6 corn rows). All plots were disked to a soil depth of $10 \mathrm{~cm}$ in the autumn within one or two days after manure and compost applications and in the spring following fertilizer application. Continuous corn system was used from 1993 to 1996 . The amounts of manure, compost, and P applied for each treatment are given in Table 2. Total $\mathrm{P}$ in manure and compost was determined using the Ignition method. ${ }^{[12]}$ When Ignition method was compared with the Nitric-Perchloric ${ }^{[13]}$ and X-ray ${ }^{[14]}$ methods, it resulted in similar total $\mathrm{P}$ as the Nitric-Perchloric, but less than that for $\mathrm{X}$-ray method (Figure 1). X-ray method seems to overestimate total $\mathrm{P}$ in cattle feedlot manure or compost.

In 1996, soil samples to a depth of $1.2 \mathrm{~m}$ were collected from all plots after corn harvest. The soil samples were divided into $0-15,15-30,30-$ $60,60-90$, and $90-120 \mathrm{~cm}$ increments and air-dried, crushed to pass a 1$\mathrm{mm}$ sieve, and analyzed for plant-available $\mathrm{P} .{ }^{[15]}$ The inorganic and total $\mathrm{P}$ fractions were determined on all soil samples, except the ones from the 90$120 \mathrm{~cm}$ soil, using the Ignition method. ${ }^{[12]}$ The organic P fraction was the difference between total $\mathrm{P}$ and inorganic $\mathrm{P}$. Water-soluble $\mathrm{P}$ in the depth fractions $0-15,15-30$, and $30-60 \mathrm{~cm}$ soil was determined using the method described by Self-Davis and Moore. ${ }^{[16]}$ Total, organic, inorganic, and water-soluble $\mathrm{P}$ fractions were also determined on the air-dried and ground samples of manure and compost using similar methods as for the soil samples.

Analysis of variance was used to analyze the data using PROC MIXED of SAS. ${ }^{[1]}$ Depth increments were used as repeated measures in this analysis. A probability level $\leq 0.05$ was considered significant.

\section{RESULTS AND DISCUSSION}

\section{Phosphorus Fractions in Manure and Compost}

Organic $\mathrm{P}$ was a small fraction of the total $\mathrm{P}$ in the applied manure and compost (Table 3). Averaged across four years, organic $\mathrm{P}$ accounted for $16 \%$ of total $\mathrm{P}$ in composted manure and $25 \%$ of total $\mathrm{P}$ in noncomposted 


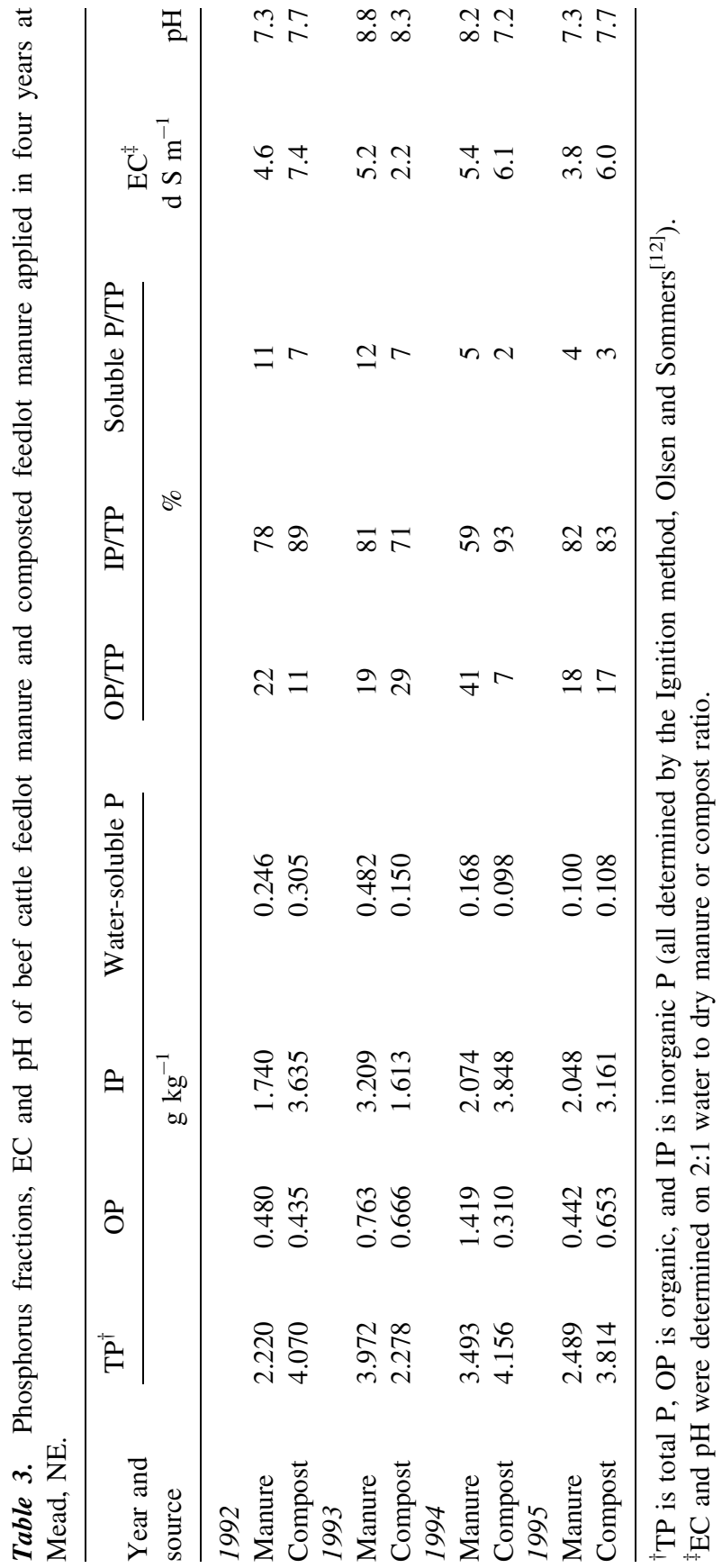


manure (Table 3). This indicated mineralization of manure organic $\mathrm{P}$ during composting process. Water-soluble $\mathrm{P}$ was a small fraction of total $\mathrm{P}$ in beef cattle feedlot manure or composted feedlot manure $(<13 \%)$ (Table 3$)$. Averaged across four years, water-soluble $\mathrm{P}$ accounted for $8 \%$ of total manure $\mathrm{P}$ and $5 \%$ of total compost $\mathrm{P}$ (Table 3). It seems that turning and mixing of manure during composting converted some of the soluble $\mathrm{P}$ to insoluble forms. Inorganic $\mathrm{P}$ was the largest fraction of manure and compost $\mathrm{P}$ ( $>75 \%$ of total $\mathrm{P})$. Sharpley and Moyer ${ }^{[18]}$ also reported high inorganic $\mathrm{P}$ ( $>63 \%$ of total $\mathrm{P}$ ) in composted and non-composted dairy manure, composted or non-composted poultry manure, and swine slurry. They concluded that dissolved inorganic $\mathrm{P}$ could be used to estimate the potential for land-applied manure or compost to enrich leachate and surface runoff $\mathrm{P}$. The inorganic $\mathrm{P}$ is high in manure since the diet of these livestock species usually contains inorganic $\mathrm{P}$.

\section{Total, Inorganic, and Organic Phosphorus in Soil}

There were significant treatments by soil depth interactions $(P<0.0001)$ for total and inorganic $\mathrm{P}$ in the soil. Manure and compost applications significantly increased total and inorganic $P$ in the surface $(0-15 \mathrm{~cm})$ soil as compared with chemical fertilizer or no treatment check (Table 4). Annual or biennial N-based manure or compost application resulted in greater total and inorganic $\mathrm{P}$ in the 0 to $15 \mathrm{~cm}$ soil than the check, chemical fertilizer, and annual P-based treatments (Table 4).

The differences observed among treatments for organic $\mathrm{P}$ in soil were not significant in all soil depths increments (Table 4). While there were sharp decreases for total and inorganic $\mathrm{P}$ with soil depth, organic $\mathrm{P}$ concentration was relatively constant for the top $60 \mathrm{~cm}$ soil indicating high organic P content in this Mollisol. The small amount of organic P applied with manure or compost did not significantly increase soil organic $\mathrm{P}$ level as compared with the check or chemical fertilizer treatments (Table 4). Sharpley et al. ${ }^{[2]}$ reported increased total, inorganic, and organic P to $30 \mathrm{~cm}$ soil depth following cattle manure application at application rates much higher than those of the $\mathrm{N}$ and P-based rates used in this study.

\section{Plant-Available and Water-Soluble Phosphorus in Soil}

There was significant treatment by soil depth interactions $(P<0.0001)$ for plant-available and water-soluble $\mathrm{P}$ in the soil. Leaching of plantavailable P (Bray and Kurtz No. 1) was observed to the $15-30 \mathrm{~cm}$ soil depth increment (Figure 2) following $4 \mathrm{yr}$ of $\mathrm{N}$-based manure [MN (manure application for corn $\mathrm{N}$ needs) and $\mathrm{MN} 2 \mathrm{Y}$ (manure for corn $\mathrm{N}$ needs for $2 \mathrm{yr}$ )] 


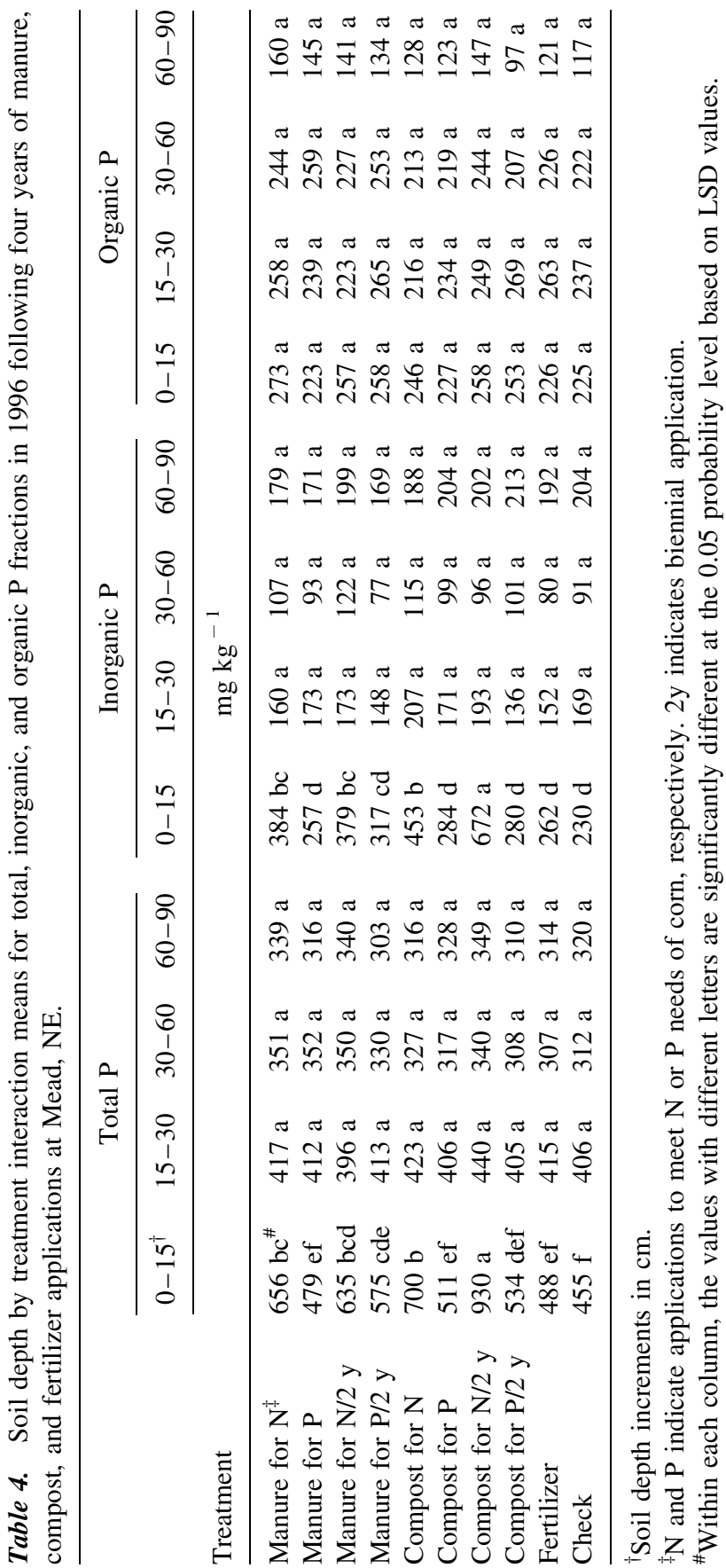




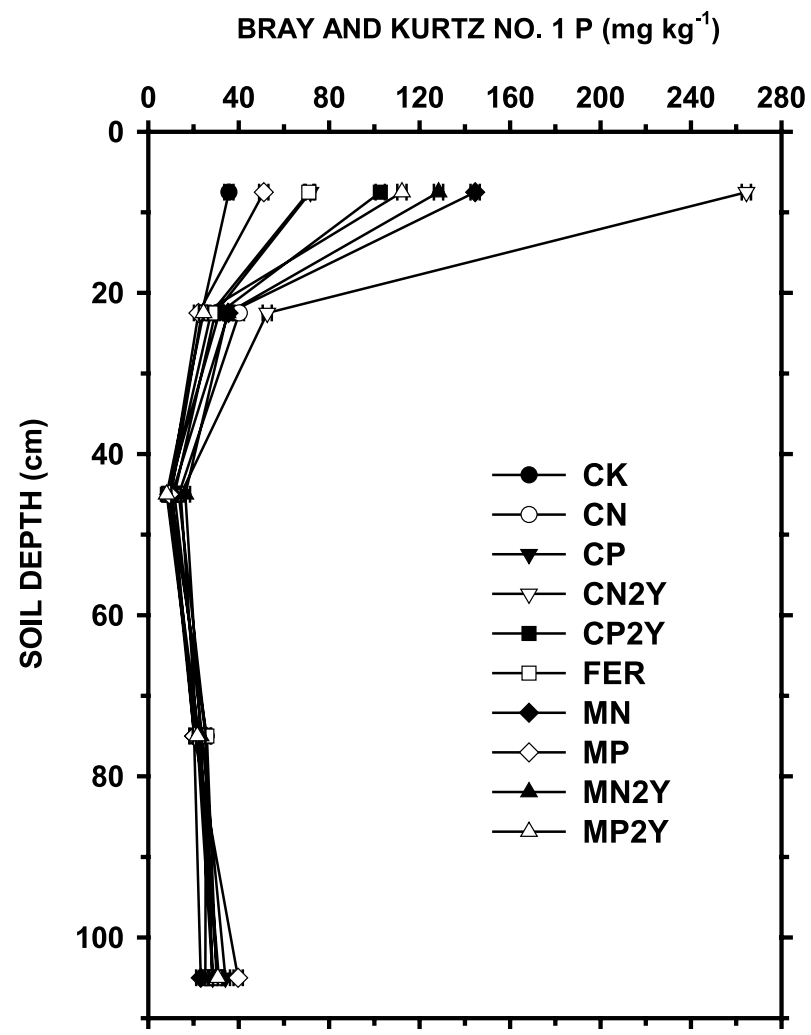

Figure 2. Plant-available $\mathrm{P}$ in the soil in 1996 following four years of $\mathrm{N}$ and P-based manure and compost applications. The horizontal bars are standard errors, $\mathrm{CN}$ is compost for $\mathrm{N}, \mathrm{CP}$ is compost for $\mathrm{P}, \mathrm{MN}$ is manure for $\mathrm{N}, \mathrm{MP}$ is manure for $\mathrm{P}, \mathrm{FR}$ is inorganic fertilizer, $\mathrm{CK}$ is check, and $2 \mathrm{Y}$ is biennial application.

and compost [CN (compost application for corn $\mathrm{N}$ needs) and $\mathrm{CN} 2 \mathrm{Y}$ (compost for corn $\mathrm{N}$ needs for $2 \mathrm{yr}$ )] applications as compared with the fertilized plots or the check. The surface $(0-15 \mathrm{~cm})$ soil $\mathrm{P}$ level was the highest for the $\mathrm{CN}$ and $\mathrm{CN} 2 \mathrm{Y}$ treatments, which also received the highest $\mathrm{P}$ application rates (Table 2). The annual P-based manure and compost treatments [MP (manure for corn $\mathrm{P}$ needs) and $\mathrm{CP}$ (compost for corn $\mathrm{P}$ needs)] resulted in similar soil $\mathrm{P}$ levels to that for the fertilizer application at all soil depth increments.

Water-soluble $\mathrm{P}$ was significantly different among treatments in the 0 to $15 \mathrm{~cm}$ soil depth increment (Figure 3) with the $\mathrm{N}$-based treatments resulting in a greater water-soluble $\mathrm{P}$ than the plots receiving chemical 


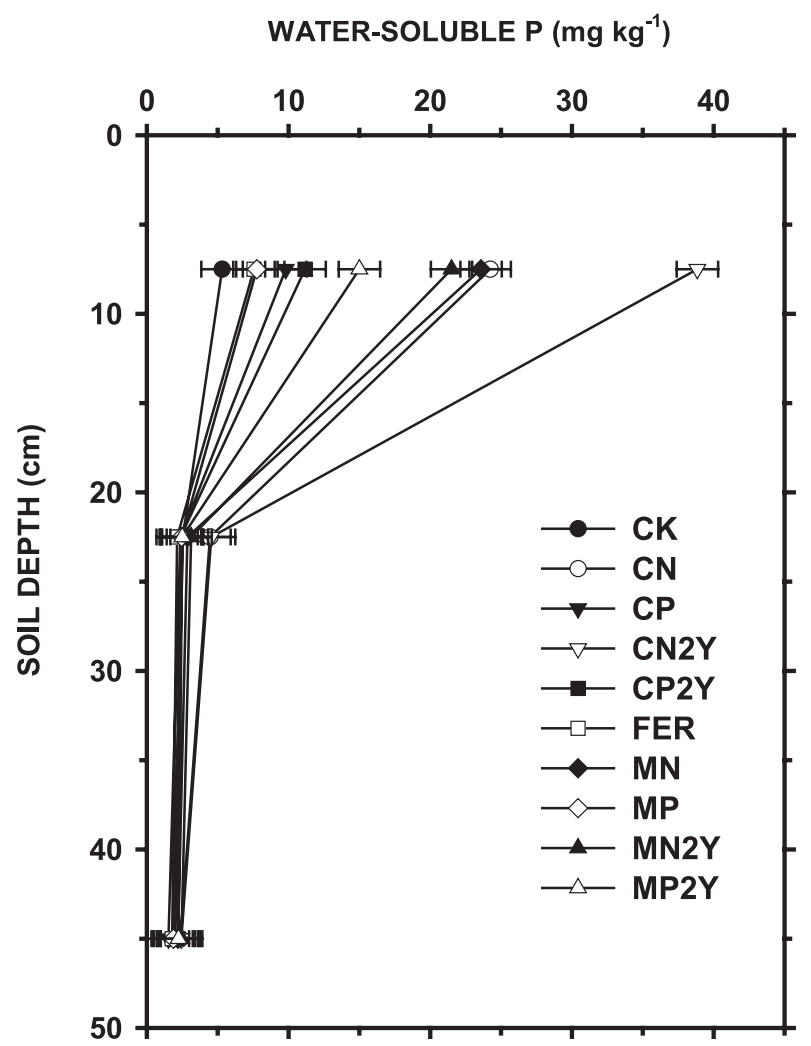

Figure 3. Water-soluble P in the soil in 1996 following four years of $\mathrm{N}$ and P-based manure and compost applications. The horizontal bars are standard errors, $\mathrm{CN}$ is compost for $\mathrm{N}, \mathrm{CP}$ is compost for $\mathrm{P}, \mathrm{MN}$ is manure for $\mathrm{N}, \mathrm{MP}$ is manure for $\mathrm{P}, \mathrm{FR}$ is inorganic fertilizer, $\mathrm{CK}$ is check, and $2 \mathrm{Y}$ is biennial application.

fertilizer. The differences in water-soluble $\mathrm{P}$ among treatments were not significant in the 15 to 30 and 30 to $60 \mathrm{~cm}$ soil depth increments. Watersoluble $\mathrm{P}$ remained in the surface layer of soil while plant-available $\mathrm{P}$ moved to the 15 to $30 \mathrm{~cm}$ soil increment.

\section{CONCLUSIONS}

More than $70 \%$ of the $\mathrm{P}$ in beef cattle feedlot manure or composted manure was inorganic. The soil organic $\mathrm{P}$ concentration was relatively constant in the top $60 \mathrm{~cm}$ soil reflecting the organic matter distribution in 
this Mollisol. Phosphorus-based manure and compost applications resulted in much less soil build up of $\mathrm{P}$ fractions in the soil than N-based. Plantavailable $\mathrm{P}$ leached to a soil depth of $30 \mathrm{~cm}$ following $\mathrm{N}$-based manure or compost application. Phosphorus leaching should be considered when manure or compost is applied to areas with shallow ground water, fluctuating ground water that moves close to the soil surface, and areas with till drainage. In most cases ground water eventually emerges as surface water and if it contains sufficient $\mathrm{P}$ can cause eutrophication. Sandy soils are especially prone to $\mathrm{P}$ leaching as these soils typically contain less adsorption sites than heavier soils.

\section{REFERENCES}

1. Eghball, B.; Binford, G.D.; Baltensperger, D.D. Phosphorus movement and adsorption in a soil receiving long-term manure and fertilizer application. J. Environ. Qual. 1996, 25, 1339-1343.

2. Sharpley, A.N.; Smith, S.J.; Stewart, B.A.; Mathers, A.C. Forms of phosphorus in soil receiving cattle feedlot waste. J. Environ. Qual. 1984, 13, 211-215.

3. Mozaffari, M.; Sims, J.T. Phosphorus availability and sorption in an Atlantic coastal plain watershed dominated by animal based agriculture. Soil Sci. 1994, 157, 97-107.

4. Sims, J.T.; Simard, R.R.; Joern, B.C. Phosphorus loss in agricultural drainage: historical perspective and current research. J. Environ. Qual. 1998, 27, 277-293.

5. Cooke, J.G.; Stub, L.; Mora, N. Fractionation of phosphorus in sediments of a wetland after a decade of receiving sewage effluent. J. Environ. Qual. 1992, 21, 726-732.

6. Chang, A.C.; Page, A.L.; Sutherland, F.H.; Grgurevic, E. Fractionation of phosphorus in sludge affected soils. J. Environ. Qual. 1983, 12, 286290.

7. Sui, Y.; Thompson, M.L.; Shang, C. Fractionation of phosphorus in a Mollisol amended with biosolids. Soil Sci. Soc. Am. J. 1999, 63, 11741180 .

8. Mozaffari, M.; Sims, J.T. Phosphorus transformation in poultry litteramended soils of Atlantic coastal plain. J. Environ. Qual. 1996, 25, 1357-1365.

9. Eghball, B.; Power, J.F. Phosphorus and nitrogen-based manure and compost application: corn production and soil phosphorus. Soil Sci. Soc. Am. J. 1999, 63, 895-901. 
10. Eghball, B. Soil properties as influenced by phosphorus- and nitrogenbased manure and compost applications. Agron. J. 2002, 94, 128-135.

11. Gilbertson, C.B.; Norstadt, F.A.; Mathers, A.C.; Holt, R.F.; Shuyler, L.R.; Barnett, A.P.; McCalla, T.M.; Onstad, C.A.; Young, R.A.; Christensen, L.A.; Van Dyne, D.L. Animal Waste Utilization on Cropland and Pastureland: A Manual for Evaluating Agronomic and Environmental Effects, USDA Utilization Res. Rep. No. 6; US Governmental Printing Office: Washington, DC, 1979.

12. Olsen, S.R.; Sommers, L.E. Phosphorus. In Methods of Soil Analysis, Part 2, 2nd Ed.; Page, A.L., Miller, R.H., Keeney, D.R., Eds.; Agronomy, ASA and SSSA: Madison, WI, 1982; Vol. 9, 403-430.

13. Johnson, C.M.; Ulrich, A. Analytical Methods for Use in Plant Analysis; Bulletin, University of California, Agricultural Experiment Station: Berkeley, CA, 1959; Vol. 766, 26-78.

14. Knudsen, D.R.; Clark, R.B.; Dening, J.L.; Pier, P.A. Plant analysis of trace elements by x-ray. J. Plant Nutr. 1981, 3, 61-75.

15. Bray, R.H.; Kurtz, L.T. Determination of total, organic, and available forms of phosphorus in soils. Soil Sci. 1945, 59, 39-45.

16. Self-Davis, M.L.; Moore, P.A., Jr. Determining water-soluble phosphorus in animal manure. In Methods of Phosphorus Analysis for Soils, Sediments, Residuals, and Waters; Pierzynski, G.M., Ed.; Southern Cooperative Series Bulletin, 2000; North Carolina State University: Raleigh, North Carolina; Vol. 396, 74-76. A publication of SERA17, Online: http://www.soil.ncsu.edu/sera17/publications/sera17-2/p_ methods2000.pdf.

17. Littell, R.C.; Milliken, G.A.; Stroup, W.W.; Wolfinger, R.D. SAS System for Mixed Models; SAS Institute, Inc.: Cary, NC, 1996.

18. Sharpley, A.N.; Moyer, B. Phosphorus forms in manure and compost and their release during simulated rainfall. J. Environ. Qual. 2000, 29, $1462-1469$. 